\title{
Increasing estrus expression in the lactating dairy cow ${ }^{1}$
}

\author{
J. A. Sauls, B. E. Voelz, S. L. Hill, L. G. D. Mendonça, and J. S. Stevenson ${ }^{2}$ \\ Department of Animal Sciences and Industry, Kansas State University, Manhattan 66506-0201
}

\begin{abstract}
Using an activity monitoring system (AMS) equipped with an accelerometer, 2 experiments were conducted to test the hypotheses that (1) enhancing progesterone before inducing luteolysis or (2) exposing cows to estradiol cypionate (ECP) or testosterone propionate (TP) after luteolysis would increase occurrence and intensity of estrus. Our goal was to determine if more cows could be detected in estrus by an AMS compared with other estrus-detection aids. In experiment 1 , cows $(\mathrm{n}=154)$ were fitted with both an AMS collar and a pressuresensitive, rump-mounted device (HeatWatch; HW) and assigned to 3 treatments: (1) no CL + progesterone insert (CIDR) for $5 \mathrm{~d}$, (2) CL only, or (3) CL + 2 CIDR inserts for $5 \mathrm{~d}$ to achieve a range in concentrations of progesterone. Prostaglandin $\mathrm{F}_{2 \alpha}$ was administered to all cows upon CIDR insert removal or its equivalent. Progesterone concentration up to $72 \mathrm{~h}$ posttreatment was greatest in CL +2 CIDR, followed by CL only, and no CL + CIDR cows. Estrus occurred 14 to $28 \mathrm{~h}$ earlier in no CL + CIDR compared with CL-bearing cows. Estrus intensity was greater for CL +2 CIDR than for CL-only cows. The AMS and HW detected 70 and $59 \%$ of cows defined to be in estrus, respectively. In experiment 2 , cows $(n=203)$ were equipped with both an AMS and a friction-activated, rump-mounted patch (Estrotect patch) and assigned to receive $1 \mathrm{mg}$ of ECP, $2 \mathrm{mg}$ of TP, or control $24 \mathrm{~h}$ after $\mathrm{PGF}_{2 \alpha}$. Concentrations of estradiol 24 and $48 \mathrm{~h}$ after treatment were greater in ECP cows compared with controls. Estrus expression detected by AMS or patches in cows defined to be in estrus tended to be greater or was greater for ECP compared with controls, respectively. Compared with controls and in response to TP or ECP, estrus occurred 8 to $18 \mathrm{~h}$ earlier and was of greater intensity for ECP cows, respectively. The AMS and patches determined 73 and $76 \%$ of cows defined to be in estrus, respectively.
\end{abstract}

\footnotetext{
Received May 27, 2016.

Accepted September 28, 2016.

${ }^{1}$ Contribution number 16-331-J from the Kansas Agricultural Experiment Station, Manhattan, KS.

${ }^{2}$ Corresponding author: jss@ksu.edu
}

Of cows exposed to the AMS, HW, or patches, 70, 61, and $75 \%$, respectively, were detected in estrus and more than $93 \%$ of these subsequently ovulated. In contrast, of the residual cows not detected in estrus, 62 to $77 \%$ ovulated in the absence of detected estrus. Only ECP was successful in inducing more expression and intensity of estrus, and proportions of cows detected in estrus exceeded $80 \%$. Given the large proportion of cows equipped with AMS collars ovulating in the absence of estrus, further research is warranted to determine if more pregnancies can be achieved by inseminating those cows not detected in estrus at an appropriate time when $\mathrm{PGF}_{2 \alpha}$ is administered to induce luteolysis.

Key words: estrus, estradiol, progesterone

\section{INTRODUCTION}

Reproductive efficiency is of critical importance to the dairy industry (Stevenson, 2014). Average estrusdetection risk $(<50 \%)$ in most US dairy herds has been identified as a major factor limiting reproductive efficiency (Lopez et al., 2005). Less than optimal days open and pregnancy risk are costly to producers. Detection of behavioral estrus plays an important role in overall reproductive management programs in most US dairies despite the widespread adoption of fixedtime ovulation-synchronization programs (Caraviello et al., 2006; Fricke et al., 2014). Furthermore, other physiological changes are associated with primary and secondary signs of estrus including vaginal cytology, $\mathrm{pH}$, electrical resistance of vaginal mucus, color and swelling of genital tissue, physical activity, changes in body temperature, uterine or ovarian blood flow, pheromones, hormones, milk yield, and DMI (Lewis and Newman, 1984; Roelofs et al., 2010; Saint-Dizier and Chastant-Maillard, 2012). In summary, expression of behavioral estrus is dependent on several factors including hormonal concentrations and physiological and environmental factors (Senger, 1994).

Approximately $76 \%$ of large dairy herds (500 or more cows) in the US house dairy cows in confinement freestall barns with concrete flooring, with $32 \%$ of those freestall operations also having turnout dry lots, with only $17 \%$ of all large operations with cows only in dry 
lots (NAHMS, 2014). One of the most important factors limiting expression of sexual behavior in lactating Holstein cows is the surface on which they are observed for estrus (Britt et al., 1986). Cows are more likely to express estrus when housed on earthen surfaces rather than on dry grooved concrete surfaces. Because milk production affects estrus expression (Lopez et al., 2005), and until recently, genetic selection for only increased milk yield was the standard practice in AI sire selection (Egger-Danner et al., 2015), cows producing greater quantities of milk have shorter and less intense periods of estrus (Lopez et al., 2005). In addition, high-yielding cows have increased metabolic rates, and to meet their nutritional and milk production requirements, dairy diets contain more concentrated energy and less forage than earlier times. As a result of high-energy diets in lactating dairy cows, hepatic blood flow is chronically increased and metabolic clearance rate of estradiol and progesterone also is increased (Sangsritavong et al., 2002), thus reducing systemic concentrations of these 2 essential steroid hormones.

Cows beginning an ovulation-synchronization program with greater progesterone concentrations had more pregnancies per AI ( $\mathbf{P} / \mathbf{A I})$ compared with cows beginning the program with lesser progesterone concentrations (Bisinotto et al., 2010; Stevenson, 2016). Furthermore, cows ovulating a follicle from the second follicular wave of the estrous cycle during elevated concentrations of progesterone had greater $\mathrm{P} / \mathrm{AI}$ than cows ovulating a first follicular wave follicle (low progesterone; Bisinotto et al., 2010). High-milk-producing dairy cows seem to lack sufficient blood concentrations of estradiol to induce estrus, ovulation, and uterine priming because of increased metabolic clearance of steroid hormones (Wiltbank et al., 2006). A greater proportion of cows expressed estrus after receiving estradiol cypionate (ECP; Sellars et al., 2006), in lieu of GnRH (Stevenson et al., 2004), to induce ovulation compared with cows that did not receive ECP. Testosterone propionate or testosterone enanthate administered without any other hormones induced mounting behavior in intact cows (Kiser et al., 1977). Estradiol (200, 400, and 800 $\mu \mathrm{g})$ and testosterone (up to 1,000 times greater doses) administered to ovariectomized nulliparous cattle increased the frequencies of occurrence of most sexual behaviors typical of cows in estrus (Katz et al., 1980). Furthermore, testosterone did not inhibit the actions of estradiol when both are administered simultaneously (Fabre-Nys and Martin, 1993).

New technologies are available to assist in detecting various physiological correlates of estrus and increased physical activity is a commonly measured correlate of estrus. Cows spend considerably more time walk- ing and less time resting and eating when in estrus (Kiddy, 1977). The average increase in activity assessed by pedometry at the time of estrus was $393 \%$ when cows were housed in freestall barns (Kiddy, 1977). With the advancement of technology, pedometers are being replaced with more sophisticated activity monitoring systems (AMS) that employ accelerometers (measures movement in 3 dimensions) to assess increased physical activity associated with estrus. Activity monitoring systems have increased reading of activity from twice daily (as with pedometers) to 12 or 24 times per day (Løvendahl and Chagunda, 2010). When an AMS (i.e., Heattime) was compared with a pedometer system (i.e., IceTag), the 2 systems had greater precision of estrus detection when compared with visual observation (Silper et al., 2015). Many newer AMS versions measure changes in activity in real time (Silper et al., 2015).

Our overall goal was to determine if more cows could be detected in estrus by an AMS compared with other estrus-detection aids. Using a market-available automated AMS, we determined if expression of estrus could be enhanced by altering the hormone milieu in which the cow was exposed before or after $\mathrm{PGF}_{2 \alpha}$-induced luteolysis. In 2 experiments, we tested the hypotheses that (1) enhancing progesterone before inducing luteolysis, or (2) exposing cows to ECP or testosterone propionate (TP) after luteolysis would increase occurrence and intensity of estrus.

\section{MATERIALS AND METHODS}

Two experiments at the Kansas State University Dairy Research and Teaching Center were conducted under the Kansas State University Institutional Animal Care and Use Committee application \#3671 (Manhattan). Lactating Holstein cows were housed at the Kansas State University Dairy Teaching and Research Center in open freestalls with roofs overhead and fed twice or thrice daily a TMR calculated to meet nutritional requirements for lactating dairy cows producing $50 \mathrm{~kg}$ of $3.5 \%$ milk (NRC, 2001). The diet consisted of alfalfa hay, corn silage, soybean meal, whole cottonseed, corn or milo grain, corn-gluten feed, vitamins, and minerals. Cows were milked thrice daily.

\section{Experiment 1}

Treatments. This experiment was conducted to determine if intensity or occurrence of estrus was altered by exposing cows to varying controlled concentrations of progesterone before $\mathrm{PGF}_{2 \alpha}$-induced luteolysis. Cows were enrolled in a study beginning at $53 \pm 3$ DIM (Figure 1) with the objective to expose them to low, me- 
dium, and high concentrations of progesterone during $5 \mathrm{~d}$ before treatment with $\mathrm{PGF}_{2 \alpha}$. Cows were administered $25 \mathrm{mg}$ of $\mathrm{PGF}_{2 \alpha}$ (Lutalyse, Zoetis Animal Health, Florham Park, NJ) $19 \mathrm{~d}$ before the final 25-mg PGF $_{2 \alpha}$ injection (d 0). Every third cow was administered an additional injection of $\mathrm{PGF}_{2 \alpha}$ on $\mathrm{d}-7$ to ensure that approximately one-third of cows enrolled did not have a functional corpus luteum (CL; retrospectively determined by progesterone concentrations) when assigned to treatments. Using transrectal ovarian ultrasonography (7.5-MHz linear-array transducer, Aloka 500V, Corometrics Medical System Inc., Wallingford, CT), presence of a CL was determined $5 \mathrm{~d}$ before administering $25 \mathrm{mg}$ of $\mathrm{PGF}_{2 \alpha}$ (d 0) to induce luteolysis. Based on presence of a CL on $\mathrm{d}-5,154$ cows were assigned to 3 treatments: $(1)$ cows $(\mathrm{n}=52)$ without a CL were administered a progesterone-impregnated (1.38 g) controlled internal drug release insert [CIDR; Zoetis Animal Health; no CL + CIDR (low progesterone)] for $5 \mathrm{~d} ;(2)$ cows $(\mathrm{n}=51)$ with a CL served as controls [CL only (medium progesterone)]; or (3) cows ( $\mathrm{n}=$ 51) with a CL were treated with 2 CIDR inserts [CL +2 CIDR (high progesterone)] for $5 \mathrm{~d}$. Before $\mathrm{PGF}_{2 \alpha}$ was administered on $\mathrm{d} 0$, ovaries of all cows again were scanned upon CIDR insert removal to verify CL status.

Strict requirements were applied to all cows defined to be in estrus (qualified cows) to determine if they should have been in true physiological estrus and demonstrated sexual behavior including standing estrus after $\mathrm{PGF}_{2 \alpha}$-induced luteolysis on $\mathrm{d} 0$. Regardless of treatment, all cows must have had a follicle $\geq 10 \mathrm{~mm}$ on $\mathrm{d} 0$ and progesterone $<0.5 \mathrm{ng} / \mathrm{mL} 72 \mathrm{~h}$ after $\mathrm{PGF}_{2 \alpha}$. In addition, for cows to qualify as low progesterone cows and be included in the analyses as qualifying no CL + CIDR treated cows, no CL could be present on d 0 and progesterone was $<2.35 \mathrm{ng} / \mathrm{mL}$, which was the largest concentration of progesterone for any no-CL cow exposed to a CIDR on d 0 in this study. This concentration $(2.35 \mathrm{ng} / \mathrm{mL})$ is consistent with mean concentrations of progesterone in ovariectomized cows exposed to a CIDR insert ranging from 1.6 to $3.0 \mathrm{ng} / \mathrm{mL}$ on d 5 after CIDR insertion (Uehlinger et al., 1995; Zuluaga and Williams, 2008). For cows to qualify as medium or high progesterone cows in the CL or CL +2 CIDR treatments, respectively, they must have had a visible CL on d 0 and progesterone $>1 \mathrm{ng} /$ $\mathrm{mL}$. Efficiency of detected estrus was assessed by the proportions of qualifying cows detected in estrus by each device. Accuracy was assessed by the proportion of qualifying cows detected in estrus that subsequently ovulated.

Cows were fitted with neck-collar-mounted AMS (MooMonitors, Dairymaster Inc., Kerney, Ireland) on $\mathrm{d}-7$. In addition, each cow also was fit with a rump-

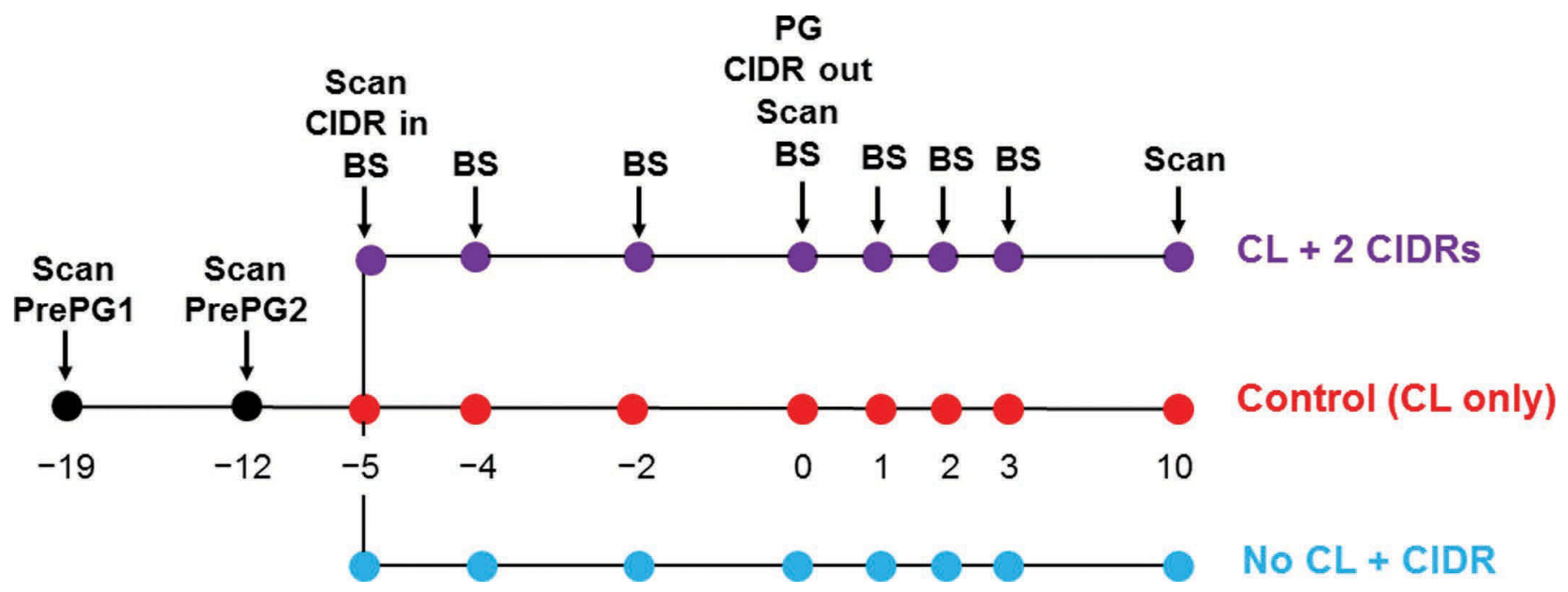

Figure 1. Experiment 1: on d -19, cows were treated with $\mathrm{PGF}_{2 \alpha}$ (PrePG1) and ovaries were scanned to determine follicle and corpus luteum (CL) location. On $\mathrm{d}-7$, ovaries were scanned to determine the presence of a CL. Every third cow was administered an additional injection of $\mathrm{PGF}_{2 \alpha}$ on $\mathrm{d}-7$ to ensure that approximately one-third of cows enrolled did not have a functional CL when assigned to treatments. Only cows assigned to the no CL + CIDR treatment received an injection of $\mathrm{PGF}_{2 \alpha}$ on $\mathrm{d}-7$ (PrePG2). Ovarian scans were performed on $\mathrm{d}-5$ to confirm CL status and cows were assigned randomly to 3 treatments: (1) no CL + CIDR inserts for 5 d, (2) CL only, and (3) CL + 2 CIDR inserts for $5 \mathrm{~d}$. An automated monitoring system (AMS) collar and rump-mounted pressure-sensitive device were fitted to each cow on d -7 . On d 0 , an injection of $\mathrm{PGF}_{2 \alpha}(\mathrm{PG})$ was administered to induce luteolysis, CIDR inserts were removed, and size of the dominant follicle was determined by ultrasound examination. Estrus activities were assessed during $7 \mathrm{~d}$ after $\mathrm{PGF}_{2 \alpha}$ injection via the AMS and a pressure-sensitive device. Blood samples (BS) were collected from a subset of cows $(\mathrm{n}=101)$ on $\mathrm{d}-5,-4,-2,0,1$, and 2 , and from all cows $(\mathrm{n}=154)$ on $\mathrm{d} 0$ and 3 . Ovarian scans were performed on d 10 to determine ovulation. CIDR $=$ progesterone-impregnated controlled internal drug release insert. Color version available online. 
mounted, pressure-sensitive device [HeatWatch $(\mathbf{H W})$, Cow Chips LLC, Manalapan, NJ]. The AMS used contains a microelectronic motion-sensing accelerometer that measured 3-dimensional movement in meters per second $^{2}$ (quantified as counts in the software). One of the AMS algorithms calculated the standard deviation of increase in motion during 3 previous hours of activity (quantified as factors in the software). Monitors uploaded information to a base station located in the holding pen of the milking parlor when cows came to the parlor to be milked thrice daily. Body condition scores $(0.25$-point increments; $1=$ thin and $5=$ fat; Ferguson et al., 1994) of cows were assessed on $\mathrm{d}-5$. On d 0, CIDR inserts were removed and all cows were administered intramuscularly $25 \mathrm{mg}$ of $\mathrm{PGF}_{2 \alpha}$ (Lutalyse; Zoetis Animal Health). Cows were monitored for estrus during $7 \mathrm{~d}$ after $\mathrm{PGF}_{2 \alpha}$ and inseminated after estrus was detected ( 8 to $12 \mathrm{~h}$ after activity threshold or after onset of first standing event).

Measurements. Transrectal ovarian ultrasonography was performed on $\mathrm{d}-5$ to measure and map location of follicles and location of each CL. Mapping was repeated on $\mathrm{d} 0$ to determine dominant follicle diameter and on d 10 to determine ovulation in cows subsequently identified to have had luteolysis.

Blood samples were collected from all cows via puncture of a coccygeal blood vessel on d 0 and $3(n=154)$. Blood samples also were collected from a subset of cows $(\mathrm{n}=101)$ on $\mathrm{d}-5,-4,-2,0,1,2$, and 3 . Samples were stored on ice and transported to the laboratory for storage at $5^{\circ} \mathrm{C}$ until serum was harvested by centrifugation $\left(1,200 \times g\right.$ at $5^{\circ} \mathrm{C}$ for $\left.15 \mathrm{~min}\right)$. Sera samples were stored at $-15^{\circ} \mathrm{C}$ until assayed for progesterone concentration by RIA (Hill et al., 2016) using ImmuChem Double Antibody progesterone ${ }^{125} \mathrm{I}$ kits (catalog \#07-170105, MP Biomedicals LLC, Orangeburg, NY); inter- and intraassay coefficients of variation were 8.0 and $4.8 \%$ for a low concentration pool, and 6.2 and $4.4 \%$ for a high concentration pool, respectively.

Variables recorded or calculated from the HW software included time of initial and final standing event, number of standing events, duration of estrus, and total standing time. Likewise, for the AMS system, time when activity first met threshold, end of threshold activity, duration of threshold activity, peak threshold activity; and average counts, peak counts, average factor, and peak factor of threshold activity were recorded or calculated from the AMS software. Both measures of counts and factors from the AMS software were defined as measures of intensity of estrus.

Statistical Analyses. Continuous outcome variables [measures of intensity of estrus, diameter of follicle on d 0, duration of threshold activity (AMS), average count and factor (AMS), duration of estrus (HW), and mounting activity (HW)] were analyzed by procedure MIXED of SAS 9.4 (SAS Inst. Inc., Cary, NC) to adjust for unequal variances. Furthermore, including the option, DDFM = SATTERTHWAITE, to the MODEL statement adjusted the degrees of freedom for unequal variances. The model of independent variables consisted of treatment (no CL + CIDR, CL +2 CIDR, and CL only), parity (primiparous vs. multiparous), treatment by parity interaction, and BCS (covariate). Concentrations of progesterone on $\mathrm{d}-5$, $-4,-2,0,1,2$, and 3 were analyzed by procedure MIXED in SAS including treatment, treatment within cow (testing error for treatment), day, and treatment $x$ day. The REPEATED option added after the model statement, with GROUP $=$ treatment $(\mathrm{n}=3)$ allowed for estimating the individual variances.

Binomial data (occurrence of estrus and ovulation, and pregnancy outcome) were analyzed by procedure GLIMMIX (METHOD = LAPLACE) in SAS. Options used in the model statement included LINK $=$ LOGIT, DIST $=$ BINOMIAL . The model consisted of the same independent variables described previously for other measured continuous variables. Orthogonal contrasts were constructed to compare (1) no CL + CIDR vs. CL only cows, and (2) CL only vs. CL +2 CIDR. A few nonorthogonal contrasts were made using ADJUST $=$ SCHEFFE, which allows valid comparisons of means with unequal replication and unequal variance.

\section{Experiment 2}

The objective of experiment 2 was to determine if estrus expression was enhanced by administration of estradiol or testosterone (precursor to estradiol synthesis) after induced luteolysis. Lactating Holstein cows were enrolled in a modified Double-Ovsynch protocol at $30 \pm 3$ DIM (Figure 2). Once-used progesterone inserts (CIDR) were placed intravaginally concurrent with the GnRH injection on $\mathrm{d}-7$ and removed $7 \mathrm{~d}$ later when cows were administered intramuscular 25 mg of $\mathrm{PGF}_{2 \alpha}$ (d 0; Prostamate, Bayer HealthCare LLC, Shawnee Mission, KS). Cows were fitted with both an AMS on $\mathrm{d}-7$, and a rump-mounted friction-activated patch (Estrotect heat detector patches, Rockway Inc., Spring Valley, WI) on d 0 . At $24 \mathrm{~h}$ after $\mathrm{PGF}_{2 \alpha}, 203$ cows were assigned randomly to 3 treatments to receive (1) $1 \mathrm{mg}$ of ECP $(\mathrm{n}=68)$, (2) $2 \mathrm{mg}$ of TP $(\mathrm{n}=68)$, or $(3)$ control $(\mathrm{n}=67)$ with no injection. At the same time as treatments were administered, all cows received a second intramuscular injection of $25 \mathrm{mg}$ of $\mathrm{PGF}_{2 \alpha}$ to maximize luteolysis. Cows were observed for patch activation twice daily for $7 \mathrm{~d}$ after the initial injection of 


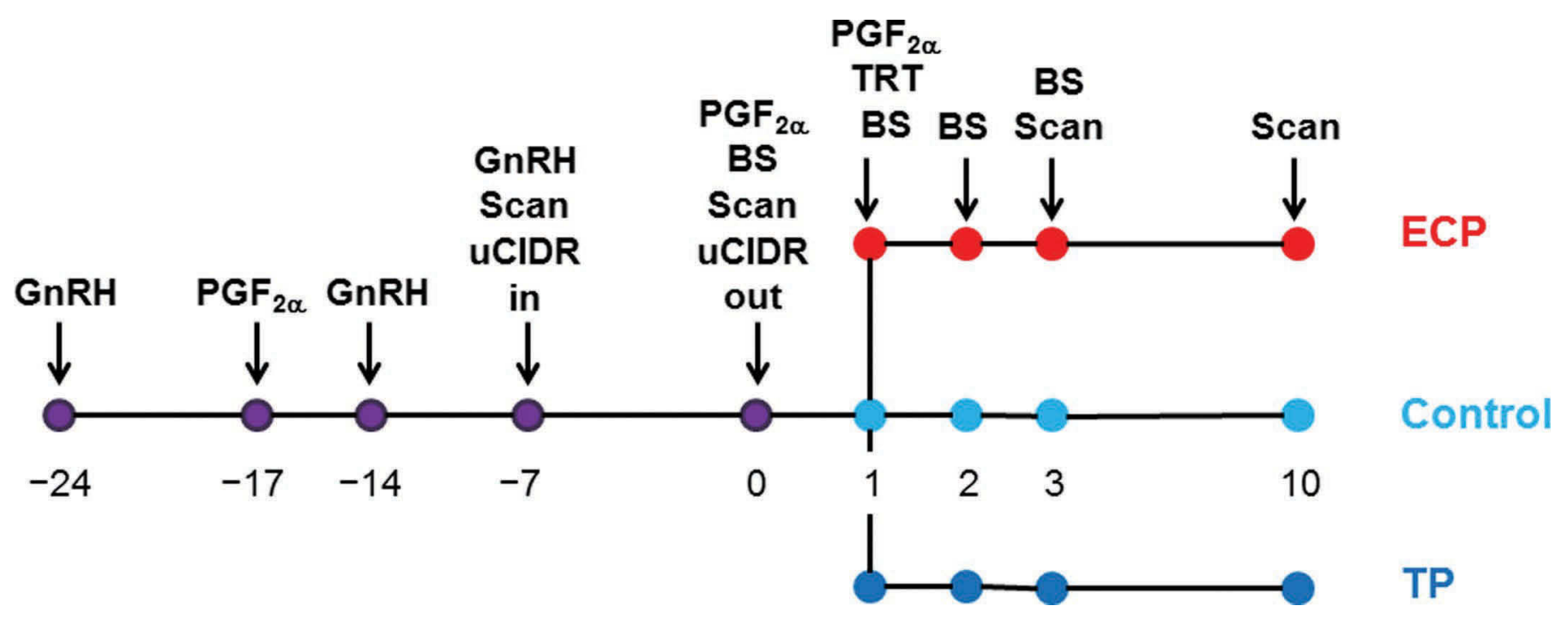

Figure 2. Experiment 2: ovulation was synchronized with $\mathrm{GnRH}(\mathrm{d}-24), \mathrm{PGF}_{2 \alpha}(\mathrm{d}-17)$, and $\mathrm{GnRH}(\mathrm{d}-14)$ before cows were exposed to a progesterone insert and concurrent $\mathrm{GnRH}$ injection on $\mathrm{d}-7$. Inserts were removed, ovarian structures were mapped, and $\mathrm{PGF}_{2 \alpha}$ was administered on $\mathrm{d}$ 0. Cows also received a second injection of $\mathrm{PGF}_{2 \alpha}$ on $\mathrm{d} 1$ and were randomly assigned to 3 treatments (TRT; $\mathrm{d}$ ): $1 \mathrm{mg}$ of estradiol cypionate (ECP), $2 \mathrm{mg}$ of testosterone propionate $(\mathrm{TP})$, or a control with no injection. Blood samples $(\mathrm{BS})$ were collected from all cows $(\mathrm{n}=$ 203 ) on $\mathrm{d} 0,1,2$, and 3 to assess progesterone and in a subset of cows $(\mathrm{n}=101)$ to measure estradiol. Ovarian scans were performed on $\mathrm{d} 10$ to determine ovulation. $\mathrm{uCIDR}=$ once-used progesterone-impregnated controlled internal drug release insert. Color version available online.

$\mathrm{PGF}_{2 \alpha}$ on $\mathrm{d} 0$. Cows were inseminated after estrus was detected ( 8 to $12 \mathrm{~h}$ after activity threshold or patches were activated). Estrus was defined to have occurred when at least 1 ovarian follicle $\geq 10 \mathrm{~mm}$ was present and progesterone $>1 \mathrm{ng} / \mathrm{mL}$ on $\mathrm{d} 0$, and progesterone was $\leq 0.5 \mathrm{ng} / \mathrm{mL}$ on $\mathrm{d} 3$ (qualifying cows as described for experiment 1).

Measurements. Transrectal ovarian ultrasonography was performed on $\mathrm{d}-7$ to determine the presence of a CL. Ovarian scanning was repeated on d 0 and 3 to measure dominant follicle diameter and on d 10 to determine ovulation after estrus expression in cows subsequently identified to have had luteolysis.

Blood samples were collected from all 203 cows via puncture of a coccygeal blood vessel on d $0,1,2$, and 3 . Samples were processed, stored, and later assayed for progesterone as described in experiment 1 . Inter- and intraassay coefficients of variation were 7.5 and $4.0 \%$ for a low concentration pool, and 5.3 and $3.8 \%$ for a high concentration pool, respectively.

Concentrations of estradiol-17 $\beta$ were measured by a modified RIA (Stevenson, 2011) in blood serum collected on $\mathrm{d} 2,3$, and 4 from a subset of cows $(\mathrm{n}=101)$. Blood serum before assay was extracted by using 10 volumes of methyl T-butyl ether (HPLC grade, Fisher Scientific, St. Louis, MO). The radioligand $\left({ }^{125}\right.$ I-labeled $17 \beta$-estradiol; 1,500 to $2,000 \mu \mathrm{Ci} / \mu \mathrm{g})$ was purchased from MP Biomedicals LLC (Solon, OH). Inter- and intraassay coefficients of variation were 11.0 and $23.0 \%$ for a low serum pool and 7.7 and $11.1 \%$ for a high serum pool, respectively. Concentrations of testosterone were measured in selected samples; however, concentrations were below the sensitivity $(10 \mathrm{pg} / \mathrm{mL})$ of the RIA.

Statistical Analyses. Continuous outcome variables [measures of intensity of estrus, diameter of follicle on d 0 , interval of threshold activity (AMS), average counts, and factors (AMS)] were analyzed by procedure MIXED of SAS 9.4 (SAS Inst. Inc., Cary, NC) as described in experiment 1 . The model of independent variables consisting of treatment (ECP, TP, and control), parity (primiparous vs. multiparous), treatment by parity interaction, and BCS (covariate). Differences in concentrations of progesterone and estradiol on $\mathrm{d} 0$, 1,2 , and 3 were analyzed by procedure MIXED in SAS as described in experiment 1.

Binomial data (occurrence of estrus and ovulation, pregnancy outcome, and proportion of cows with progesterone $<0.5 \mathrm{ng} / \mathrm{mL} 72 \mathrm{~h}$ post $\mathrm{PGF}_{2 \alpha}$ injection) were analyzed by procedure GLIMMIX in SAS as described in experiment 1. Procedure LOGISTIC in SAS also was applied to selected binomial traits. Adjusted odds ratios (AOR) and 95\% confidence intervals are reported in the text. The models consisted of the same independent variables described previously for the continuous variables. Orthogonal contrasts were constructed to compare (1) ECP vs. control, and (2) TP vs. control. Other nonorthogonal contrasts were made as described in experiment 1. 


\section{RESULTS}

\section{Experiment 1}

Mean concentrations of progesterone in a subset of qualifying cows defined to be in estrus (follicle $\geq 10 \mathrm{~mm}$ and progesterone $>1 \mathrm{ng} / \mathrm{mL}$ at $\mathrm{PGF}_{2 \alpha}$ injection and progesterone $\leq 0.5 \mathrm{ng} / \mathrm{mL} 72 \mathrm{~h}$ later) relative to the injection of $\mathrm{PGF}_{2 \alpha}$ to induce luteolysis demonstrated that concentrations of progesterone on $\mathrm{d}-5$ for cows bearing CL were greater $(P<0.05)$ compared with the no $\mathrm{CL}+\mathrm{CIDR}$ treatment (Figure 3A). Progesterone
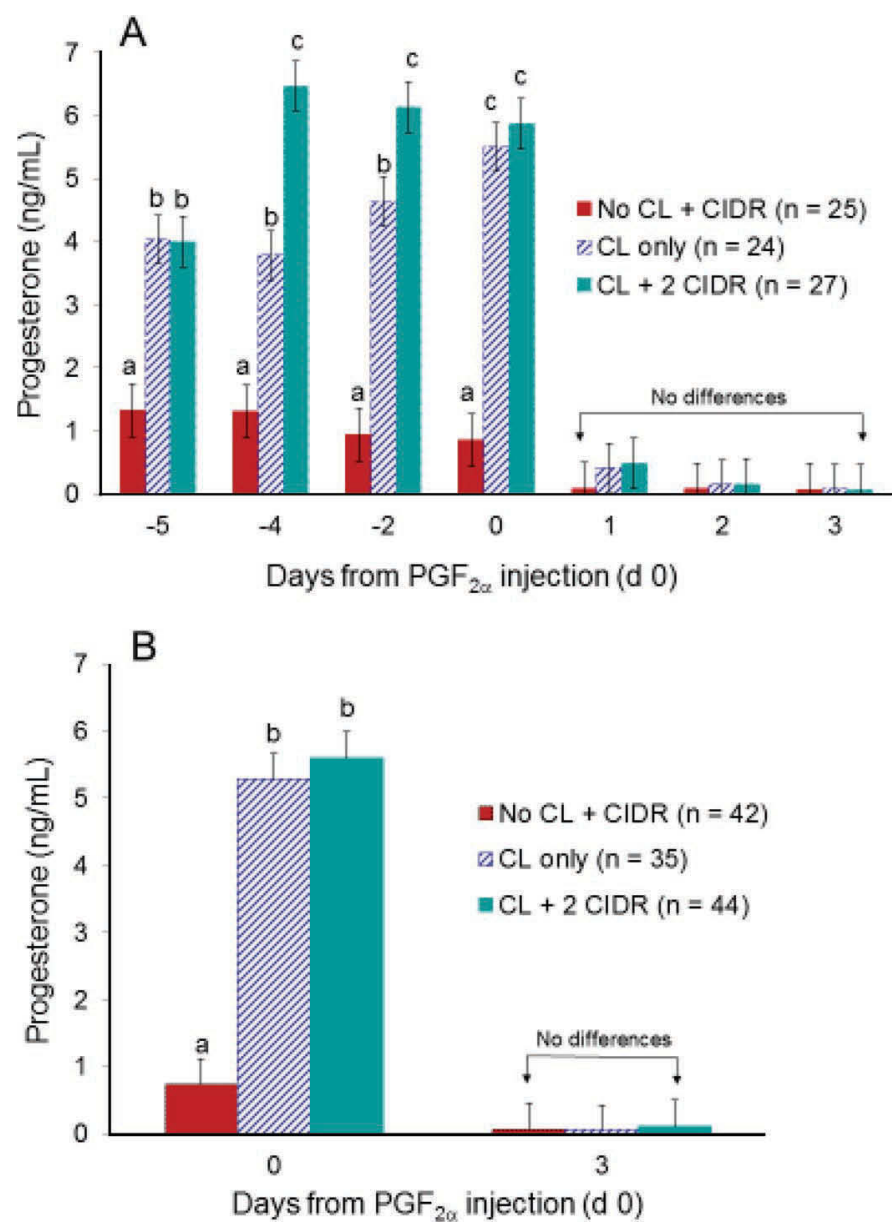

Figure 3. Least squares means $( \pm \mathrm{SE})$ concentrations of progesterone relative to injection of $\mathrm{PGF}_{2 \alpha}(\mathrm{d} 0)$ for a subset $(\mathrm{A})$ or all $(\mathrm{B})$ qualifying cows defined to be estrus in 3 treatments on $\mathrm{d}-5$ (experiment 1): (1) corpus luteum (CL) only, (2) no CL + CIDR insert for 5 $\mathrm{d}$, or $(3) \mathrm{CL}+2 \mathrm{CIDR}=$ the presence of a CL and 2 CIDR inserts for $5 \mathrm{~d}$. On d 0, CIDR inserts were removed and all cows received $\mathrm{PGF}_{2 \alpha}$. To be included herein, qualifying cows must have met the following criteria: (1) a follicle $\geq 10 \mathrm{~mm}$ in diameter at $\mathrm{PGF}_{2 \alpha}$ on $\mathrm{d} 0$; (2) concentrations of progesterone $\leq 0.5 \mathrm{ng} / \mathrm{mL} 72 \mathrm{~h}$ after $\mathrm{PGF}_{2 \alpha}$ injection; and (3) for cows in either CL treatment, progesterone $>1 \mathrm{ng} / \mathrm{mL}$ on 0 or $<2.35 \mathrm{ng} / \mathrm{mL}$ for cows with no CL + CIDR insert. Least squares means bearing different letters within day differ $(P<0.05)$. Error bars represent SE. CIDR = progesterone-impregnated controlled internal drug release insert. Color version available online. concentrations increased after CIDR insertion and differed $(P<0.01)$ among treatments from $\mathrm{d}-4$ through $\mathrm{d}-2$, with CL +2 CIDR cows having the greatest $(P$ $<0.01)$ concentrations of progesterone compared with CL only and no CL + CIDR cows. After PGF Pa $_{2 \alpha}$ was administered on $\mathrm{d} 0$, mean concentrations of progesterone decreased to $\leq 0.5 \mathrm{ng} / \mathrm{mL}$ by d 3 .

In all enrolled qualified cows, concentrations of progesterone were greater $(P \leq 0.05)$ on $\mathrm{d} 0$ for all CL-bearing cows compared with no CL + CIDR cows. Concentrations of progesterone decreased thereafter to $\leq 0.5 \mathrm{ng} / \mathrm{mL}$ and did not differ on d 3 (Figure 3B). In addition, average diameter of putative preovulatory follicle on d 0 was greater $(P<0.01)$ in no CL + CIDR cows $(17.2 \pm 0.5 \mathrm{~mm})$ compared with CL only $(13.9$ $\pm 0.4 \mathrm{~mm})$ or CL +2 CIDR cows $(14.5 \pm 0.5 \mathrm{~mm})$, respectively.

Neither occurrence of estrus nor ovulation risk for all enrolled cows differed among treatments (Table 1). As assessed by the AMS, occurrence of estrus ranged from 56 to $67 \%$. Of all cows that expressed estrus, ovulation risk varied from 89 to $100 \%$ among treatments. As assessed by HW, occurrence of estrus varied from 45 to $61 \%$. Of cows that expressed estrus, ovulation risk ranged from 93 to 100\%. Expression of estrus occurred 1.6 to 1.8 times greater $(P<0.01)$ in primiparous than multiparous cows; however, ovulation risk did not differ between primiparous and multiparous cows. Furthermore, estrus expression, but not ovulation risk, increased $(P<0.05)$ with increasing BCS.

Occurrence of estrus and ovulation for qualifying cows also is summarized in Table 1. As assessed by the AMS, occurrence of estrus ranged from 62 to $79 \%$. Of qualifying cows that expressed estrus, ovulation risk ranged from 88 to $100 \%$ and did not differ among treatments. As determined by HW, occurrence of estrus ranged from 51 to $69 \%$. Of qualifying cows that expressed estrus, ovulation risk ranged from 93 to $100 \%$ and did not differ among treatments. Consistent with all enrolled cows, 1.5 to 1.9 times more $(P$ $<0.01$ ) qualifying primiparous than multiparous cows expressed estrus, but parity had no effect on ovulation risk. Cows having greater BCS were more $(P<0.01)$ likely to express estrus, but risk of ovulation was not affected by BCS.

Characteristics of estrus of qualifying cows are summarized in Table 2 as assessed by the AMS and HW (pressure-sensitive device). As determined by the AMS, onset of estrus was detected earlier $(P<0.01)$ after $\mathrm{PGF}_{2 \alpha}$ for cows in the no CL + CIDR treatment compared with cows bearing CL. Duration of estrus (hours when activity exceeded threshold) quantified by the AMS averaged $11.98 \pm 1.1 \mathrm{~h}$. Although peak factor (measure of the standard deviation of increase in peak 
Table 1. Occurrence of estrus and ovulation in all cows and qualifying cows defined to be in estrus fitted with an activity monitoring system (AMS) and a rump-mounted pressure-sensitive device (experiment 1)

\begin{tabular}{|c|c|c|c|c|c|}
\hline Item [\% (no.)] & \multicolumn{3}{|c|}{ Treatment $^{1}$} & \multicolumn{2}{|c|}{$P$-value ${ }^{2}$} \\
\hline \multirow{2}{*}{\multicolumn{6}{|c|}{ AMS }} \\
\hline & \multicolumn{5}{|c|}{ Estrus expression $^{3}$} \\
\hline All cows ${ }^{4}$ & $66.9(52)$ & $62.9(51)$ & $56.3(51)$ & 0.695 & 0.541 \\
\hline Qualifying cows ${ }^{5}$ & $70.3(42)$ & $79.5(35)$ & $61.9(44)$ & 0.480 & 0.204 \\
\hline \multicolumn{6}{|c|}{ Estrus and ovulation ${ }^{6}$} \\
\hline \multicolumn{6}{|c|}{ Pressure-sensitive device } \\
\hline \multicolumn{6}{|c|}{ Estrus expression } \\
\hline All cows & $61.2(52)$ & $56.2(51)$ & $45.2(51)$ & 0.637 & 0.306 \\
\hline Qualifying cows & $59.5(42)$ & $69.3(35)$ & $51.3(44)$ & 0.902 & 0.216 \\
\hline \multicolumn{6}{|c|}{ Estrus and ovulation } \\
\hline All cows & $93.7(32)$ & $100(30)$ & $95.6(23)$ & 0.388 & 0.304 \\
\hline Qualifying cows & $92.8(28)$ & $100(24)$ & $95.4(22)$ & 0.371 & 0.317 \\
\hline
\end{tabular}

${ }^{1}$ Corpus luteum $(\mathrm{CL})$ only; no CL + CIDR $=$ no CL + CIDR insert $(\mathrm{d}-5)$ for $5 \mathrm{~d}$; or CL +2 CIDR inserts $(\mathrm{d}-5)$ for $5 \mathrm{~d}$. On $\mathrm{d} 0 \mathrm{CIDR}$ inserts were removed and all cows received $\mathrm{PGF}_{2 \alpha}$.

${ }^{2}$ Orthogonal contrasts.

${ }^{3}$ Percentage of cows expressing activity assessed by AMS or pressure-sensitive patches.

${ }^{4}$ All cows enrolled in the experiment.

${ }^{5}$ Only cows with a follicle $\geq 10 \mathrm{~mm}$ in diameter at $\mathrm{PGF}_{2 \alpha}$ on $\mathrm{d} 0$ and concentrations of progesterone $\leq 0.5 \mathrm{ng} / \mathrm{mL} 72 \mathrm{~h}$ after $\mathrm{PGF}{ }_{2 \alpha}$ injection. For cows in either CL treatment, progesterone $>1 \mathrm{ng} / \mathrm{mL}$ on d 0 or $<2.35 \mathrm{ng} / \mathrm{mL}$ for cows with no CL + CIDR insert.

${ }^{6}$ Percentage of cows that ovulated subsequent to detected estrus.

activity during $3 \mathrm{~h}$ ), as a measure of estrus intensity by the AMS, was greater $(P<0.05)$ for cows in the CL +2 CIDR treatment compared with CL only, no other measures of estrus intensity (mean count, peak count, and mean factor) differed among treatments. Neither parity nor BCS affected any of the characteristics of estrus or intensity of estrus.

Based on the pressure-sensitive device, onset of estrus after $\mathrm{PGF}_{2 \alpha}$ occurred earlier $(P<0.05)$ in no $\mathrm{CL}+$ CIDR cows compared with CL-bearing cows (Table 2).

Table 2. Characteristics of estrus (LSM \pm SEM) determined by automated activity monitoring system (AMS) or by a rump-mounted pressuresensitive device for qualifying cows defined to be in estrus (experiment 1$)^{1}$

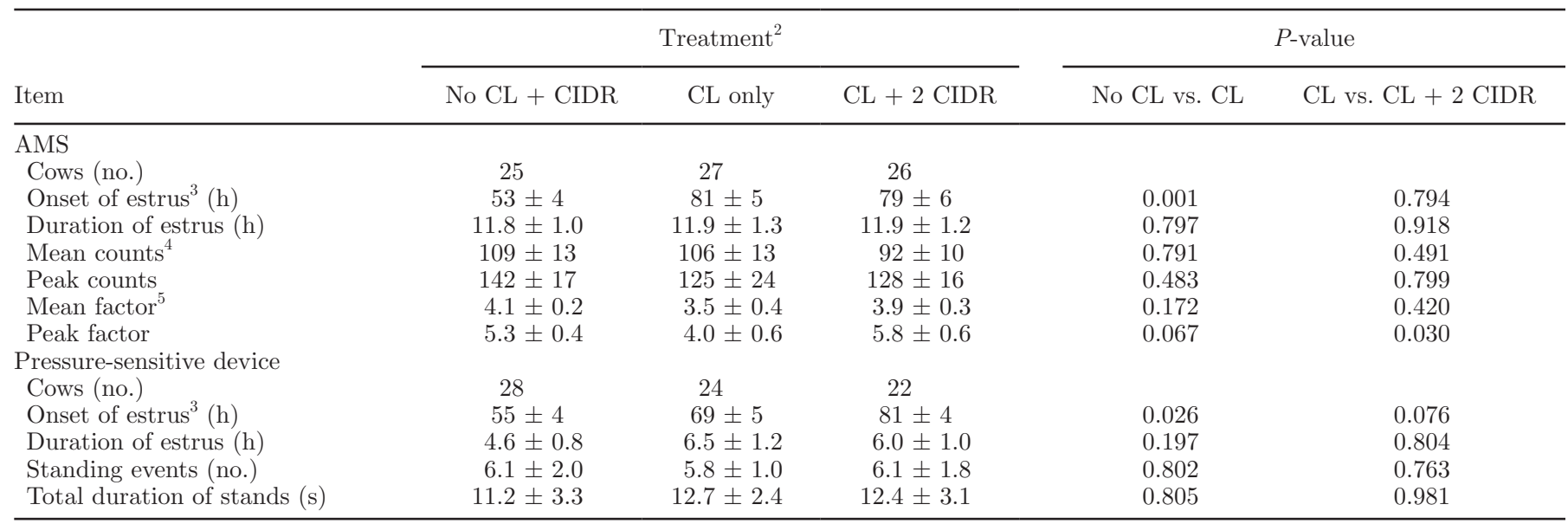

${ }^{1}$ Only cows with a follicle $\geq 10 \mathrm{~mm}$ in diameter at $\mathrm{PGF}_{2 \alpha}$ on $\mathrm{d} 0$ and concentrations of progesterone $\leq 0.5 \mathrm{ng} / \mathrm{mL} 72 \mathrm{~h}$ after PGF ${ }_{2 \alpha}$ injection. For cows in either CL treatment, progesterone $>1 \mathrm{ng} / \mathrm{mL}$ on d 0 or $<2.35 \mathrm{ng} / \mathrm{mL}$ for cows with no CL + CIDR insert.

${ }^{2}$ Corpus luteum $(\mathrm{CL})$ only; no CL + CIDR $=$ no $\mathrm{CL}+$ CIDR insert $(\mathrm{d}-5)$ for $5 \mathrm{~d}$; or CL +2 CIDR inserts $(\mathrm{d}-5)$ for $5 \mathrm{~d}$. On $\mathrm{d} 0 \mathrm{CIDR}$ inserts were removed and all cows received $\mathrm{PGF}_{2 \alpha}$.

${ }^{3}$ Interval to estrus from removal of CIDR insert, $\mathrm{PGF}_{2 \alpha}$, or both.

${ }^{4}$ Arbitrary units quantify motion ( $\mathrm{m}$ per $\mathrm{s}^{2}$ ) detected by AMS.

${ }^{5}$ Standard deviation of increase in motion from the previous $3 \mathrm{~h}$ of activity. 
Mean duration of estrus (interval between first and last recorded standing event) ranged from $4.6 \pm 0.8$ to 6.5 $\pm 1.2 \mathrm{~h}$ and did not differ among treatments. Furthermore, various measures of estrus intensity (number or duration of total standing events) did not differ among treatments.

Pregnancy per AI in all enrolled cows was 36.3, 51.2, and $37.2 \%$ for no CL + CIDR $(\mathrm{n}=37)$, CL only ( $\mathrm{n}=$ $37)$, and $\mathrm{CL}+2$ CIDR $(\mathrm{n}=32)$ treatments, respectively. For qualifying cows defined to be in estrus, $\mathrm{P} / \mathrm{AI}$ was $35.5,54.7$, and $32.6 \%$ for no CL + CIDR $(\mathrm{n}=31)$, CL only $(\mathrm{n}=30)$, and CL +2 CIDR $(\mathrm{n}=29)$ treatments, respectively. Neither parity nor BCS affected pregnancy outcomes.

\section{Experiment 2}

Concentrations of progesterone in all qualifying cows $(\mathrm{n}=203)$ enrolled in experiment 2 at the time of $\mathrm{PGF}_{2 \alpha}$ through $72 \mathrm{~h}$ after injection are illustrated in Figure 4. Mean concentrations of progesterone exceeded $5 \mathrm{ng} / \mathrm{mL}$ before the first of $2 \mathrm{PGF}_{2 \alpha}$ injections were administered and decreased to $\leq 0.5 \mathrm{ng} / \mathrm{mL}$ by $\mathrm{d} 2$. Concentrations of estradiol relative to the initial injection of $\mathrm{PGF}_{2 \alpha}$ in a subset of qualifying cows $(\mathrm{n}=101)$ on $\mathrm{d} 2$ and 3 were greater $(P<0.01)$ in cows treated with ECP compared with TP and controls (Figure 5). In addition, average

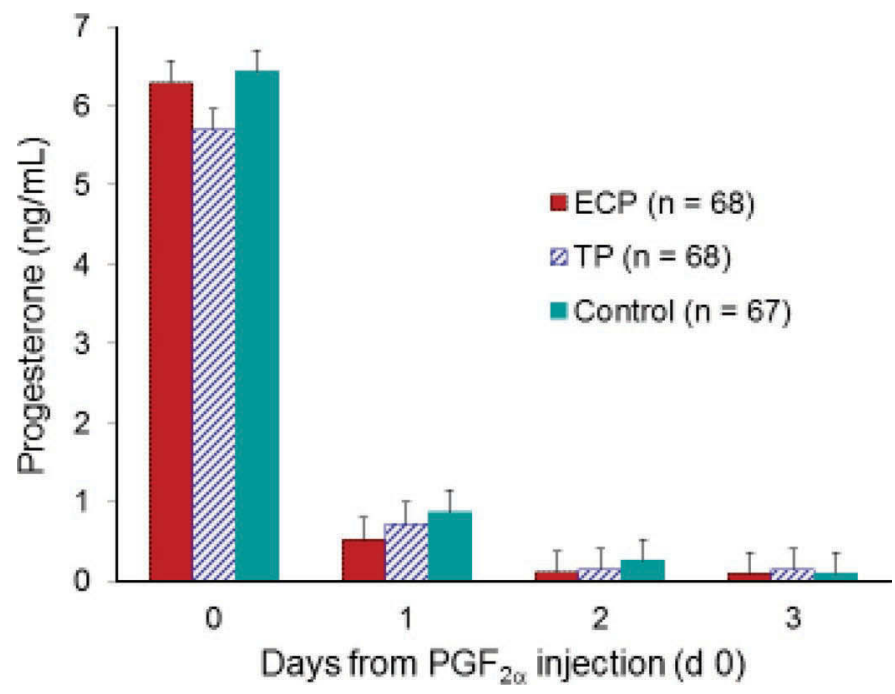

Figure 4. Least squares means $( \pm \mathrm{SE})$ concentrations of progesterone relative to initial injection of $\mathrm{PGF}_{2 \alpha}(\mathrm{d} 0)$ for cows assigned to 3 treatments administered on $\mathrm{d} 1$ (experiment 2): (1) $\mathrm{ECP}=1 \mathrm{mg}$ of estradiol cypionate, (2) $\mathrm{TP}=2 \mathrm{mg}$ of testosterone propionate, or (3) control $=$ no treatment injection. All cows received a second injection of $\mathrm{PGF}_{2 \alpha}$ on $\mathrm{d} 1$. Only qualifying cows with a follicle $\geq 10 \mathrm{~mm}$ in diameter at $\mathrm{PGF}_{2 \alpha}$ and concentrations of progesterone $>1 \mathrm{ng} / \mathrm{mL}$ before and $\leq 0.5 \mathrm{ng} / \mathrm{mL} 72 \mathrm{~h}$ after $\mathrm{PGF}_{2 \alpha}$ injection are included. Error bars represent $\mathrm{SE}$. Color version available online.

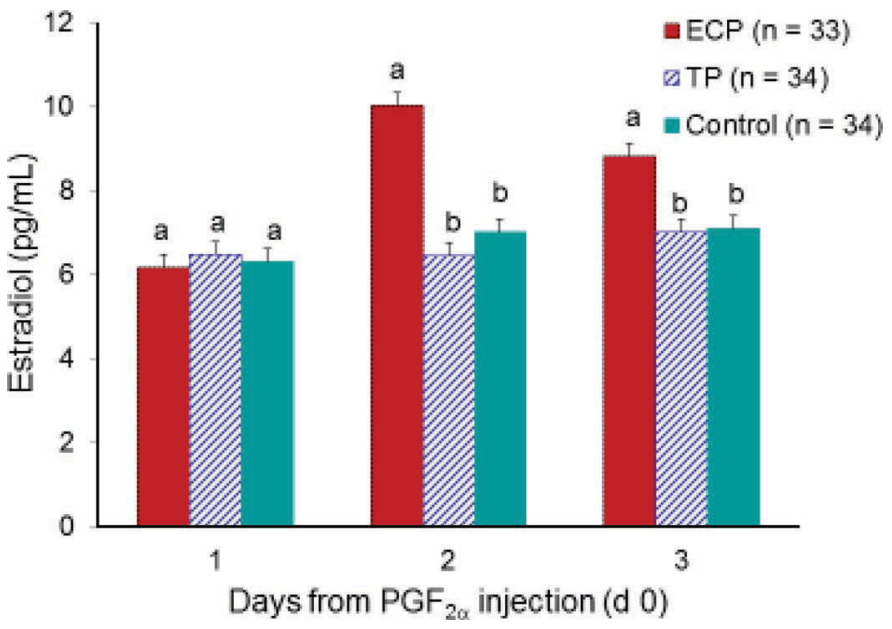

Figure 5. Least squares means $( \pm \mathrm{SE})$ concentrations of estradiol relative to initial $\mathrm{PGF}_{2 \alpha}$ injection (d 0 ) for a subset of qualifying cows defined to be in estrus assigned to 3 treatments administered on $\mathrm{d} 1$ (experiment 2): (1) ECP $=1 \mathrm{mg}$ of intramuscular estradiol cypionate, (2) $\mathrm{TP}=2 \mathrm{mg}$ of intramuscular testosterone propionate, or (3) control $=$ no treatment injection $(\mathrm{d} 1)$. All cows received a second injection of $\mathrm{PGF}_{2 \alpha}$ on $\mathrm{d} 1$. Only qualifying cows with a follicle $\geq 10 \mathrm{~mm}$ in diameter at $\mathrm{PGF}_{2 \alpha}$ and concentrations of progesterone $>1 \mathrm{ng} / \mathrm{mL}$ before and $\leq 0.5 \mathrm{ng} / \mathrm{mL} 72 \mathrm{~h}$ after $\mathrm{PGF}_{2 \alpha}$ injection are included. Least squares means bearing different letters within day differ $(P<0.05)$. Error bars represent SE. Color version available online.

diameter of putative preovulatory follicle on d 0 did not differ before treatments were applied in ECP (14.0 $\pm 0.3 \mathrm{~mm})$, TP $(14.0 \pm 0.3 \mathrm{~mm})$, or control cows $(14.4$ $\pm 0.3 \mathrm{~mm})$.

Estrus expression and ovulation risk for all cows enrolled in experiment 2 are summarized in Table 3. Estrus expression determined by AMS varied from 67 to $79 \%$ among treatments, and of the cows that expressed estrus, ovulation risk ranged from 87 to $95 \%$. More ECP cows tended $(P=0.09)$ to have activated patches compared with controls. Of the cows that expressed estrus as assessed by activated patches, ovulation risk ranged from 88 to $98 \%$ among treatments. Primiparous cows tended $(P=0.11 ;$ AOR $=1.93,95 \%$ $\mathrm{CI}=0.978$ to 3.82 ) to be more likely to express estrus than multiparous cows. Body condition had no effect on expression of estrus or ovulation risk.

Estrus expression and ovulation risk for qualifying cows also are summarized in Table 3. As determined by the AMS, occurrence of estrus did not differ among treatments. Of qualifying cows that expressed estrus by the AMS, ovulation risk ranged from 88 to $98 \%$. More $(P=0.056)$ ECP cows with Estrotect-activated patches were detected in estrus compared with control cows. Of qualifying cows identified in estrus, ovulation risk varied from 89 to $98 \%$ (Table 3$)$. Although more $(P$ $=0.03 ; \mathrm{AOR}=2.28 ; 95 \% \mathrm{CI}=1.07$ to 4.85$)$ qualify- 
Table 3. Occurrence of estrus and ovulation in all cows and qualifying cows defined to be in estrus fitted with an activity monitoring system (AMS) and a friction-activated patch (experiment 2)

\begin{tabular}{|c|c|c|c|c|c|}
\hline \multirow[b]{2}{*}{ Item [\% (no.)] } & \multicolumn{3}{|c|}{ Treatment $^{1}$} & \multicolumn{2}{|c|}{$P$-value ${ }^{2}$} \\
\hline & $\mathrm{ECP}$ & $\mathrm{TP}$ & Control & ECP vs. control & $\mathrm{TP}$ vs. control \\
\hline \multicolumn{6}{|l|}{ AMS } \\
\hline \multicolumn{6}{|l|}{ Estrus expression ${ }^{3}$} \\
\hline All cows ${ }^{4}$ & $78.7(68)$ & $67.4(68)$ & $70.2(67)$ & 0.260 & 0.740 \\
\hline Qualifying cows ${ }^{5}$ & $81.2(62)$ & $67.5(59)$ & $69.4(59)$ & 0.138 & 0.827 \\
\hline \multicolumn{6}{|c|}{ Estrus and ovulation ${ }^{6}$} \\
\hline \multicolumn{6}{|c|}{ Friction-activated patch } \\
\hline \multicolumn{6}{|c|}{ Estrus expression } \\
\hline All cows & $84.3(63)$ & $67.7(64)$ & $71.4(60)$ & 0.092 & 0.667 \\
\hline Qualifying cows & $88.0(58)$ & $66.1(55)$ & $72.7(53)$ & 0.056 & 0.487 \\
\hline \multicolumn{6}{|c|}{ Estrus and ovulation } \\
\hline All cows & $98.1(53)$ & $88.4(43)$ & $92.9(42)$ & 0.309 & 0.501 \\
\hline Qualifying cows & $98.0(51)$ & $88.9(36)$ & $94.6(37)$ & 0.490 & 0.365 \\
\hline
\end{tabular}

${ }^{1}$ Cows received an injection of $\mathrm{PGF}_{2 \alpha}(\mathrm{d} 0)$ and were assigned randomly to 3 treatments: $\mathrm{ECP}=1 \mathrm{mg}$ of estradiol cypionate; TP $=2$ mg of testosterone propionate; control $=$ no treatment injection. Treatments were administered on $\mathrm{d} 1$ concurrent with a second injection of $\mathrm{PGF}_{2 \alpha}$.

${ }^{2}$ Orthogonal contrasts.

${ }^{3}$ Percentage of cows expressing activity assessed by AMS or friction-activated patches.

${ }^{4}$ All cows enrolled in the experiment.

${ }^{5}$ Cows with a follicle $\geq 10 \mathrm{~mm}$ in diameter at $\mathrm{PGF}_{2 \alpha}$, concentrations of progesterone $>1 \mathrm{ng} / \mathrm{mL}$ before and $\leq 0.5 \mathrm{ng} / \mathrm{mL} 72 \mathrm{~h}$ after PGF $2 \alpha$ injection.

${ }^{6}$ Percentage of cows that ovulated subsequent to detection of estrus.

ing primiparous cows were likely to express estrus than multiparous cows, BCS did not influence expression of estrus or ovulation risk.

Characteristics of estrus assessed by the AMS are summarized in Table 4. Compared with controls, onset of estrus occurred earlier $(P<0.001)$ after treatment with ECP or tended $(P=0.102)$ to be earlier after TP than for controls. Mean duration of estrus ranged from $9.5 \pm 0.9$ and $10.3 \pm 0.6 \mathrm{~h}$ among treatments. Compared with controls, average peak counts suggested greater intensity of estrus after ECP $(P=0.031)$ or after TP $(P=0.070)$. Other measures of estrus intensity (mean count, mean factor, and peak factor) did not differ among treatments. Although primiparous cows expressed estrus sooner $(P=0.01)$ after treatment than multiparous cows $(50 \pm 2.6$ vs. $60 \pm 2.6 \mathrm{~h})$, and duration of estrus was greater $(P=0.03)$ in primiparous than multiparous cows $(10.9 \pm 0.6$ vs. $8.8 \pm 0.6 \mathrm{~h})$, respectively. No other measures of estrus intensity were affected by parity or BCS.

Table 4. Characteristics of estrus (LSM \pm SEM) determined by an activity monitoring system (AMS) for qualifying cows defined to be in estrus (experiment 2$)^{1}$

\begin{tabular}{|c|c|c|c|c|c|}
\hline \multirow[b]{2}{*}{ Item } & \multicolumn{3}{|c|}{ Treatment $^{2}$} & \multicolumn{2}{|c|}{$P$-value ${ }^{3}$} \\
\hline & $\mathrm{ECP}$ & $\mathrm{TP}$ & Control & ECP vs. control & $\mathrm{TP}$ vs. control \\
\hline Treatment to estrus (h) & $46 \pm 2$ & $56 \pm 2$ & $64 \pm 5$ & 0.001 & 0.102 \\
\hline Duration of estrus (h) & $10.3 \pm 0.6$ & $9.5 \pm 0.9$ & $9.7 \pm 0.7$ & 0.526 & 0.859 \\
\hline Mean counts ${ }^{4}$ & $114 \pm 6$ & $106 \pm 6$ & $99 \pm 7$ & 0.132 & 0.455 \\
\hline Peak counts & $203 \pm 13$ & $199 \pm 15$ & $166 \pm 11$ & 0.031 & 0.070 \\
\hline
\end{tabular}

${ }^{1}$ Cows with a follicle $\geq 10 \mathrm{~mm}$ in diameter at $\mathrm{PGF}_{2 \alpha}$, concentrations of progesterone $>1 \mathrm{ng} / \mathrm{mL}$ before and $\leq 0.5 \mathrm{ng} / \mathrm{mL} 72 \mathrm{~h}$ after $\mathrm{PGF}$ injection.

${ }^{2}$ Cows received an injection of $\mathrm{PGF}_{2 \alpha}$ (d 0$)$ and assigned randomly to 3 treatments: $\mathrm{ECP}=1 \mathrm{mg}$ of estradiol cypionate; TP $=2 \mathrm{mg}$ of testosterone propionate; control $=$ no treatment injection. Treatments were administered on $\mathrm{d} 1$ concurrent with a second injection of $\mathrm{PGF}_{2 \alpha}$.

${ }^{3}$ Orthogonal contrasts.

${ }^{4}$ Arbitrary units quantify motion ( $\mathrm{m}$ per $\mathrm{s}^{2}$ ) detected by AMS.

${ }^{5}$ Standard deviation of increase in motion from the previous $3 \mathrm{~h}$ of activity. 
Table 5. Percentage of qualifying cows defined to be in estrus (efficiency) during $7 \mathrm{~d}$ after $\mathrm{PGF}_{2 \alpha}$-induced luteolysis, to have ovulated, or both (accuracy) detected by an activity monitoring system (AMS), pressuresensitive devices, or friction-activated patches in experiments 1 and 2

\begin{tabular}{|c|c|c|c|}
\hline Item $[\%$ (no./no.)] & AMS & $\begin{array}{c}\text { Pressure-sensitive } \\
\text { devices }\end{array}$ & $\begin{array}{c}\text { Friction-activated } \\
\text { patches }\end{array}$ \\
\hline \multicolumn{4}{|l|}{ Experiment $1^{1}$} \\
\hline Estrus expression & $66.9(81 / 121)$ & $61.2(74 / 121)$ & $\ldots$ \\
\hline Ovulation & $93.8(76 / 81)$ & $96.0(71 / 74)$ & $\ldots$ \\
\hline No ovulation & $6.2(5 / 81)$ & $4.0(3 / 74)$ & $\ldots$ \\
\hline No estrus expression & $33.1(40 / 121)$ & $38.8(47 / 131)$ & $\ldots$ \\
\hline Ovulation & $70.0(28 / 40)$ & $76.6(36 / 47)$ & $\ldots$ \\
\hline No ovulation & $30.0(12 / 40)$ & $23.4(11 / 47)$ & $\ldots$ \\
\hline \multicolumn{4}{|l|}{ Experiment $2^{2}$} \\
\hline Estrus expression & $72.2(130 / 180)$ & $\ldots$ & $74.7(124 / 166)$ \\
\hline Ovulation & $93.8(122 / 130)$ & $\ldots$ & $94.3(117 / 124)$ \\
\hline No ovulation & $6.2(8 / 130)$ & $\ldots$ & $5.7(7 / 124)$ \\
\hline No estrus expression & $27.8(50 / 180)$ & $\ldots$ & $25.3(42 / 166)$ \\
\hline Ovulation & $62.0(31 / 50)$ & $\ldots$ & $61.9(26 / 42)$ \\
\hline No ovulation & $38.0(19 / 50)$ & $\ldots$ & $38.1(16 / 42)$ \\
\hline
\end{tabular}

${ }^{1}$ Only cows with a follicle $\geq 10 \mathrm{~mm}$ in diameter at $\mathrm{PGF}_{2 \alpha}$ on $\mathrm{d} 0$ and concentrations of progesterone $\leq 0.5 \mathrm{ng} /$ $\mathrm{mL} 72 \mathrm{~h}$ after $\mathrm{PGF}_{2 \alpha}$ injection. For cows in either CL treatment, progesterone $>1 \mathrm{ng} / \mathrm{mL}$ on d 0 or $<2.35 \mathrm{ng} /$ $\mathrm{mL}$ for cows with no CL + CIDR insert.

${ }^{2}$ Cows with a follicle $\geq 10 \mathrm{~mm}$ in diameter at $\mathrm{PGF}_{2 \alpha}$, concentrations of progesterone $>1 \mathrm{ng} / \mathrm{mL}$ before, and $\leq 0.5 \mathrm{ng} / \mathrm{mL} 72 \mathrm{~h}$ after $\mathrm{PGF}_{2 \alpha}$ injection.

Pregnancy per AI resulting from AI for all cows enrolled in experiment 2 was $40.6,34.7$, and $29.3 \%$ for the $\operatorname{ECP}(\mathrm{n}=62), \operatorname{TP}(\mathrm{n}=52)$, and control $(\mathrm{n}=51)$ cows, respectively. For qualifying cows defined to be in estrus, $\mathrm{P} / \mathrm{AI}$ was $39.8,32.0$, and $31.1 \%$ for $\mathrm{ECP}(\mathrm{n}=58)$, $\mathrm{TP}(\mathrm{n}=45)$, and control $(\mathrm{n}=44)$ cows, respectively. Neither parity nor BCS affected pregnancy outcomes.

\section{Efficiency and Accuracy of Detected Estrus}

Efficiency and accuracy of the 3 methods employed in both experiments to detect estrus were compared in all qualifying cows. The proportions of enrolled cows meeting these criteria that were detected in estrus (efficiency), ovulated, or both (accuracy) are summarized in Table 5. Efficiency of detected estrus ranged from 61 to $75 \%$. Ovulation risk (accuracy of detected estrus) for the cows detected by the AMS, pressure-sensitive devices, and friction-activated patches were 94, 96, and $94 \%$, respectively. Of particular interest was the 25 to $39 \%$ of cows that did not express estrus in which ovulation risk ranged from 62 to $77 \%$ in the absence of estrus.

\section{DISCUSSION}

The current studies evaluated if (1) enhancing concentrations of progesterone before inducing luteolysis; or (2) exposing cows to ECP or TP after luteolysis would increase occurrence and intensity of estrus differently depending on the type of estrus-detection method employed. It has been reported that progesterone treatment increased concentrations of estradiol receptors in the ventromedial hypothalamus of the ewe (Caraty and Skinner, 1999), suggesting a possible priming effect of progesterone in the brain for various estradiol-mediated functions. The treatments implemented in experiment 1 caused concentrations of progesterone to differ by 24 $\mathrm{h}$ and to remain different until $24 \mathrm{~h}$ before $\mathrm{PGF}_{2 \alpha}$ injection. In experiment 1 , cows within the no CL + CIDR treatment may have come to estrus earlier compared with those cows bearing CL because their preovulatory follicles were larger and progesterone clearance in the absence of a CL occurred more quickly upon removal of the supplemental progesterone insert. Furthermore, dominant follicles exposed to lesser than greater concentrations of progesterone, and resulting increased LH pulses, grow faster and become larger (Savio et al., 1993; Cerri et al., 2011), consistent with the observed larger follicles in the no CL + CIDR cows compared with CL-bearing cows.

Previous research has shown that the detection efficiency of identifying estrus is improved when heifers are treated with progesterone (Carrick and Shelton, 1969). Postpartum dairy cows initiating the Ovsynch protocol before first AI without a CL and treated with 2 CIDR inserts, which increased endogenous concentrations of progesterone, were reported to have greater pregnancy risk than untreated herd mates and similar fertility as CL-bearing contemporary controls starting Ovsynch in diestrus (Bisinotto et al., 2013, 2015). Peak factor assessed by the AMS, and used to quantify intensity 
of estrus, was greater for CL +2 CIDR, in which concentrations of progesterone were greatest during $5 \mathrm{~d}$ before $\mathrm{PGF}_{2 \alpha}$, compared with cows having a CL only in experiment 1 . In contrast, pregnancy per $\mathrm{AI}$ was numerically less in cows with a CL that were exposed to 2 CIDR inserts, suggesting that excessive progesterone may be counterproductive to achieving normal fertility.

An increase in estrus intensity supports the idea that progesterone priming may affect the threshold at which estradiol stimulates the GnRH surge (Caraty and Skinner, 1999). The increase in intensity of estrus detected in the CL +2 CIDR cows may have occurred because of their greater circulating progesterone concentrations. Circulating concentrations of progesterone are determined by 2 factors: (1) secretion rate of progesterone by the CL and (2) metabolic clearance rate via hepatic enzymatic functions. Concentrations of progesterone achieved in the CL + CIDR cows were perhaps greater than the range of 4.0 to $5.8 \mathrm{ng} / \mathrm{mL}$ detected during mid diestrus in lactating dairy cows (Sartori et al., 2004; Bisinotto et al., 2013). Moreover, a single CIDR insert achieves only $20 \%$ of the circulating progesterone concentrations of high-producing dairy cows in mid diestrus (Cerri et al., 2009; Bisinotto et al., 2013), which is consistent with concentrations achieved in our no CL + CIDR treatment. Previous research has shown that metestrual concentrations of progesterone in sub-fertile dairy cows increased more slowly after estrus compared with those in more fertile heifers (Shelton et al., 1990; Inskeep and Dailey, 2005). Studies have shown that high-producing dairy cows have greater metabolic clearance of steroids compared with nonlactating dairy cows (Sangsritavong et al., 2002; Wiltbank et al., 2006).

Action of estradiol on the hypothalamus in the relative absence of progesterone is responsible for estrus (Allrich, 1994). Substituting ECP for GnRH in a timed AI protocol resulted in more cows in estrus after the induction of luteolysis (Stevenson et al., 2004). Concentrations of estradiol were greater in our ECP-treated cows than in the non-estradiol-treated cows by $24 \mathrm{~h}$ after treatment, and subsequently, ECP and TP cows came to estrus earlier than control cows. Peak counts, used to quantify estrus intensity, were greater for ECP and TP (tendency) compared with control cows, indicating a causative effect of estradiol. Although studies have examined metabolic clearance of progesterone (Lemley et al., 2010), it has been hypothesized that insufficient estradiol produces inadequate stimulation of the hypothalamus, resulting in a lack of behavioral estrus (Pereira et al., 2016). A previous study determined metabolic clearance rate of estradiol per metabolic weight for a fasted compared with a well-fed dairy cow to be 0.23 versus $0.36 \mathrm{~L}$ per min per $\mathrm{kg}$ of $\mathrm{BW}^{0.75}$
(Sangsritavong et al., 2002), which agreed with results in gilts $\left(0.11\right.$ to $0.24 \mathrm{~L}$ per min per $\mathrm{kg}$ of $\mathrm{BW}^{0.75}$; Christenson et al., 1985). Experiment 2 demonstrated that cows supplemented with ECP had increased circulating concentrations of estradiol during approximately $48 \mathrm{~h}$ after ECP treatment as well as increased estrus expression compared with control cows. Further research is warranted to investigate how metabolic clearance rate affects concentrations of estradiol and subsequent estrus expression.

Reports indicate that fertility is increased in cows that express estrus at or near the fixed-time AI (Galvão et al., 2004; Pereira et al., 2014, 2016). Estrus expression also was associated with better estrus-ovulation synchronization and greater pregnancy per AI from 32 to $60 \mathrm{~d}$ after AI (Pereira et al., 2016). Increased estrus expression after treatment with ECP in experiment 2 is in agreement with previous reports (Pereira et al., 2016). According to the 2-cell, 2-gonadotropin model, cholesterol is converted to progesterone and then to androstenedione by theca interna cells of the follicle (Fortune and Quirk, 1988). Androstenedione is then transported to granulosa cells where, under the influence of $\mathrm{P} 450_{\text {arom }}$, it is converted to estradiol-17 $\beta$ (Hansel and Convey, 1983). Part of experiment 2 was to determine if the limiting factor for estrus expression was insufficient conversion of precursor steroid hormones to estradiol. If a greater dose of TP $(>2 \mathrm{mg})$ had been used in experiment 2, perhaps sufficient estradiol production may have occurred in cows treated with TP and greater expression of estrus may have occurred. Nevertheless, both TP- and ECP-treated cows expressed estrus earlier and had greater (ECP) or tended to have greater (TP) intensity than controls, suggesting a biological effect of the 2-mg dose employed. Furthermore, most of the AMS intensity measures (peak counts and peak factor) fell in the mid-range of means between those of ECP-treated cows and controls.

Cows in estrus express more mounting activity in pastures or dry lots than in free-stall or tie-stall housing systems (De Silva et al., 1981; Palmer et al., 2010). Furthermore, cows with greater milk production seem to have shorter and less intense periods of estrus (Lopez et al., 2005), consistent with our observations of less estrus intensity in multiparous, greater milk-producing cows. Cows observed in estrus when housed on an earthen surface have longer durations of estrus and more total standing events compared with cows on a dry, grooved concrete surface (Helmer and Britt, 1985). When given the option by experimental design, cows in estrus preferred to spend $73 \%$ of their estrual periods on earthen rather than concrete surfaces and their mounting activity on dirt was increased 3 to 15 times 
(Vailes and Britt, 1990). Given many dairy facilities have concrete surfaces, secondary signs of estrus are a significant addition to detecting estrus.

Increased physical activity is highly correlated with estrus. Activity during estrus increased by $400 \%$ in $93 \%$ of estrous periods (Kiddy, 1977), which has formed the basis for developing many pedometer and accelerometer devices on the market for dairy producers today (Stevenson et al., 2014). Quantifying pedometry associated with estrus has served as a means of estrus detection as early as the 1970s (Roelofs et al., 2010). The current study used a market-available AMS to determine estrus and was compared with a pressure-sensitive device and friction-activated patch. In experiments 1 and 2, none of the devices employed were superior to the others in detecting more cows in estrus when time of estrus was synchronized. Estrus-detection risk ranged from 61 to $75 \%$ for cows in experiment 1 and 2, which is in agreement with earlier findings in which another AMS and friction-activated patches were employed (Valenza et al., 2012). Approximately two-thirds of cows considered properly synchronized (follicle diameter $\geq 10 \mathrm{~mm}$ at time of first GnRH injection, and concentrations of progesterone $\geq 1 \mathrm{ng} / \mathrm{mL}$ at the time of $\mathrm{PGF}_{2 \alpha}$ and $\leq 0.5$ $\mathrm{ng} / \mathrm{mL} 48 \mathrm{~h}$ after $\mathrm{PGF}_{2 \alpha}$ ) were detected in estrus based on an AMS and friction-activated patches (Valenza et al., 2012). Furthermore, the proportion of cows detected in estrus did not differ between an AMS or heat mount detector (Valenza et al., 2012), similar to the results of the present studies.

The present experiments found that of qualifying cows not detected in estrus by any of the 3 methods, 62 to $77 \%$ subsequently ovulated, which results are consistent, but of greater magnitude than findings of 53 and $65 \%$ of nondetected cows subsequently ovulating in another report (Valenza et al., 2012).

Both studies support the value of various estrusdetection tools for herds that are not achieving estrusdetection risks in excess of 60 to $70 \%$. Herds that are achieving estrus-detection risks equal to those demonstrated in the present study will not likely find added economic value of employing an AMS that does not significantly improve their current estrus-detection risk. Because of the lesser likelihood of mounting and standing activities during estrus for cows housed exclusively in freestall barns with concrete surfaces compared with cows housed in dry lots or pastures (De Silva et al., 1981; Vailes and Britt, 1990; Palmer et al., 2010), free-stall housed cows equipped with AMS are more to likely have greater increases in estrus-detection risk. Given that approximately $76 \%$ of large dairy herds (500 or more cows) in the US house dairy cows in confinement freestall barns with concrete flooring, with $32 \%$ of those freestall operations also having turnout dry lots, and only $17 \%$ of all large operations with cows only in dry lots (NAHMS, 2014), the potential for improving estrus-detection risk exists in many herds. Therefore, a greater cost-benefit may be accrued for dairy operations that employ AMS in freestall herds housed on concrete compared with herds on dry lots or pasture. The AMS clearly have greater value than static onetime-use methods such as patches, tail chalk, or tail paint because of the time-date information and 24-h surveillance provided via the AMS software. Furthermore, not demonstrated by the present experiments is the value of the AMS in identifying first returns to estrus in cows that failed to conceive and subsequently decreasing inter-insemination intervals and their ability to monitor activity $24 \mathrm{~h}$ per day.

\section{CONCLUSIONS}

Only the ECP treatment successfully induced more cows in estrus, but proportions of cows detected barely exceeded $80 \%$. Given the large proportion of cows ovulating in the absence of estrus, further research is warranted when AMS are employed to determine if more pregnancies can be achieved by inseminating cows not detected in estrus at an appropriate time after $\mathrm{PGF}_{2 \alpha}$-induced luteolysis. An AMS is likely an appropriate tool for herds achieving less estrus-detection risk achieved in the current experiments $(70 \%$ without estradiol). Although efficiency and accuracies of the 3 estrus-expression methods employed did not differ, the AMS and pressure-sensitive rump-mounted pressure detectors offer continuous monitoring of activity independent of visual assessment of friction-activated patches by herd personnel and potentially offer greater surveillance options in all cows, particularly herds in which cows are housed on concrete with less than ideal footing conditions.

\section{ACKNOWLEDGMENTS}

We gratefully acknowledge the Kansas State University Dairy Teaching and Research Center manager, M. V. Scheffel, and his staff for their care of cows and assistance in conducting these experiments. We thank W. S. Fausnett for performing the radioimmunoassays for progesterone and L. Hill (both at Kansas State University) for assistance with sample collection. Donations of CIDR inserts, Lutalyse, and Factrel by Zoetis Animal Health (Roger Saltman); Prostamate by Bayer (Richard Markham), Estrotect patches by Rockway Inc. (Boyd Dingus) are gratefully acknowledged. 


\section{REFERENCES}

Allrich, R. D. 1994. Estrus, new devices, and monitoring; endocrine and neural control of estrus in dairy cows. J. Dairy Sci. 77:2738 2744.

Bisinotto, R. S., L. O. Castro, M. B. Pansani, C. D. Narciso, N. Martinez, L. D. Sinedino, T. L. C. Pinto, M. S. Van de Burgwal, H. M. Bosman, R. S. Surjus, W. W. Thatcher, and J. E. P. Santos. 2015. Progesterone supplementation to lactating dairy cows without a corpus luteum at initiation of the Ovsynch protocol. J. Dairy Sci. 98:2515-2528

Bisinotto, R. S., R. C. Chebel, and J. E. Santos. 2010. Follicular wave of the ovulatory follicle and not cyclic status influences fertility of dairy cows. J. Dairy Sci. 93:3578-3587.

Bisinotto, R. S., E. S. Ribeiro, F. S. Lima, N. Martinez, L. F. Greco, L. F. S. P. Barbosa, P. P. Bueno, L. F. S. Scagion, W. W. Thatcher, and J. E. P. Santos. 2013. Targets progesterone supplementation improves fertility in lactating dairy cows without a corpus luteum at the initiation of the timed artificial insemination protocol. J. Dairy Sci. 96:2214-2225.

Britt, J. H., R. G. Scott, J. D. Armstrong, and M. D. Whitacre. 1986. Determinants of estrous behavior in lactating Holstein cows. J. Dairy Sci. 69:2195-2202.

Caraty, A., and D. C. Skinner. 1999. Progesterone priming is essential for the full expression of the positive feedback effect of estradiol in inducing the preovulatory gonadotropin releasing hormone surge in the ewe. Endocrinology 140:165-170.

Caraviello, D. Z., K. A. Weigel, P. M. Fricke, M. C. Wiltbank, M. J. Florent, N. B. Cook, K. V. Nordlund, N. R. Zwald, and C. L. Rawson. 2006. Survey of management practices on reproductive performance of dairy cattle on large US commercial farms. J. Dairy Sci. 89:4723-4735.

Carrick, M. J., and J. N. Shelton. 1969. Estrogen-progesterone relationships in induction of estrus in spayed heifers. J. Endocrinol. 45:99-109.

Cerri, R. L. A., R. C. Chebel, F. Rivera, C. D. Narciso, R. A. Oliveira, W. W. Thatcher, and J. E. P. Santos. 2011. Concentration of progesterone during the development of the ovulatory follicle: 1. Ovarian and embryonic responses. J. Dairy Sci. 94:3342-3351.

Cerri, R. L. A., H. M. Rutigliano, R. G. Bruno, and J. E. P. Santos. 2009. Progesterone concentration, follicular development and induction of cyclicity in dairy cows receiving intravaginal progesterone insets. Anim. Reprod. Sci. 110:56-70.

Christenson, R. K., J. J. Ford, and D. A. Redmer. 1985. Metabolic clearance and production rates of estradiol and progesterone during pubertal and postpubertal development in gilts. J. Reprod. Fertil. 75:247-253.

De Silva, A. W. M. V., G. W. Anderson, F. C. Gwazdauskas, M. L. McGilliard, and J. A. Lineweaver. 1981. Interrelationships with estrous behavior and conception in dairy cattle. J. Dairy Sci. 64:2409-2418

Egger-Danner, C., J. B. Cole, J. E. Pryce, N. Gengler, B. Heringstad, A. Bradley, and K. F. Stock. 2015. Invited review: Overview of new traits and phenotyping strategies in dairy cattle with a focus on functional traits. Animal 9:191-207.

Fabre-Nys, C., and G. B. Martin. 1993. Analysis of the hormonal control of female sexual behavior and the preovulatory LH surge in the ewe: Roles of quantity of estradiol and duration of its presence. Horm. Behav. 27:108-121.

Ferguson, J. D., D. T. Galligan, and N. Thomsen. 1994. Principal descriptors of body condition score in Holstein cows. J. Dairy Sci. 77:2695-2703.

Fortune, J. E., and S. M. Quirk. 1988. Regulation of steroidogenesis in bovine preovulatory follicles. J. Anim. Sci. 66(Suppl. 2):1-8.

Fricke, P. M., P. D. Carvalho, J. O. Giordano, A. Valenza, G. Lopes Jr., and M. C. Amundson. 2014. Expression and detection of estrus in dairy cows: The role of new technologies. Animal 8:134-143.

Galvão, K. N., J. E. Santos, S. O. Juchem, R. L. Cerri, A. C. Coscioni, and M. Villaseñor. 2004. Effect of addition of a progesterone intravaginal insert to a timed insemination protocol using estradiol cypionate on ovulation rate, pregnancy rate, and late embryonic loss in lactating dairy cows. J. Anim. Sci. 82:3508-3517.

Hansel, W., and E. M. Convey. 1983. Physiology of the estrous cycle. J. Anim. Sci. 57:404-424.

Helmer, S. D., and J. H. Britt. 1985. Mounting behavior as affected by stage of estrous cycle in Holstein heifers. J. Dairy Sci. 68:12901296.

Hill, S. L., D. M. Grieger, K. C. Olson, J. R. Jaeger, C. R. Dahlen, M. R. Crosswhite, N. Negrin Pereira, S. R. Underdahl, B. W. Neville, J. Ahola, M. C. Fischer, G. E. Seidel, and J. S. Stevenson. 2016 $\mathrm{GnRH}$ increased pregnancy risk in suckled beef cows not detected in estrus and subjected to a split-time artificial insemination program. J. Anim. Sci. 94. https://doi.org/10.2527/jas.2016-0582.

Inskeep, E. K., and R. A. Dailey. 2005. Embryonic death in cattle. Vet. Clin. North Am. Food Anim. Pract. 21:437-461.

Katz, L. S., E. A. B. Oltenacu, and R. H. Foote. 1980. The behavioral responses in ovariectomized cattle to either estradiol, testosterone, androstenedione, or dihydrotestosterone. Horm. Behav. 14:224-235.

Kiddy, C. A. 1977. Variation in physical activity as an indication of estrus in dairy cows. J. Dairy Sci. 60:235-243.

Kiser, T. E., J. H. Britt, and H. D. Ritchie. 1977. Testosterone treatment of cows for use in detection of estrus. J. Anim. Sci. 44:10301035.

Lemley, C. O., T. A. Wilmoth, L. R. Tager, K. M. Krause, and M. E. Wilson. 2010. Effect of a high cornstarch diet on hepatic cytochrome P450 2C and 3A activity and progesterone half-life in dairy cows. J. Dairy Sci. 93:1012-1021.

Lewis, G. S., and S. K. Newman. 1984. Changes throughout estrous cycles of variables that might indicate estrus in dairy cows. J. Dairy Sci. 67:146-152.

Lopez, H., D. Z. Caraviello, L. D. Satter, P. M. Fricke, and M. C. Wiltbank. 2005. Relationship between level of milk production and multiple ovulations in lactating dairy cows. J. Dairy Sci. 88:27832793.

Løvendahl, P., and M. G. Chagunda. 2010. On the use of physical activity monitoring for estrus detection in dairy cows. J. Dairy Sci. 93:249-259.

National Animal Health Monitoring System (NAHMS). 2014. Dairy Cattle Management Practices in the United States. Table E.1.f., p. 263. Accessed May 16, 2016. http://www.aphis.usda.gov/nahms.

NRC. 2001. Nutritional Requirements of Dairy Cattle. 7th rev. edition. Natl. Acad. Sci., Washington, DC.

Palmer, M. A., G. Olmos, L. A. Boyle, and J. F. Mee. 2010. Estrus detection and estrus characteristics in housed and pastured HolsteinFriesian cows. Theriogenology 74:255-264.

Pereira, M. H. C., A. D. Rodrigues, R. J. De Carvalho, M. C. Wiltbank, and J. L. Vasconcelos. 2014. Increasing length of an estradiol and progesterone timed artificial insemination protocol decreases pregnancy loss in lactating dairy cows. J. Dairy Sci. 97:1454-1464.

Pereira, M. H. C., M. C. Wiltbank, and J. L. M. Vasconcelos. 2016. Expression of estrus improves fertility and decreases pregnancy losses in lactating dairy cows that receive artificial insemination or embryo transfer. J. Dairy Sci. 99:2237-2247.

Roelofs, J., F. López-Gatius, R. H. F. Hunter, F. J. C. M. van Eerdenburg, and C. Hazen. 2010. When is a cow in estrus? Clinical and practical aspects. Theriogenology 74:327-344.

Saint-Dizier, M., and S. Chastant-Maillard. 2012. Towards an automated detection of oestrus in dairy cattle. Reprod. Domest. Anim. 47:1056-1061.

Sangsritavong, S., D. K. Combs, R. Sartori, L. E. Armentano, and M. C. Wiltbank. 2002. High feed intake increases liver blood flow and metabolism of progesterone and estradiol-17 $\beta$ in dairy cattle. J. Dairy Sci. 85:2831-2842.

Sartori, R., J. M. Haughian, R. D. Shaver, G. J. M. Rosa, and M. C Wiltbank. 2004. Comparison of ovarian function and circulating steroids in estrous cycles of Holstein heifers and lactating cows. J. Dairy Sci. 87:905-920.

Savio, J. D., W. W. Thatcher, G. R. Morris, K. Entwistle, M. Drost, and M. R. Mattiacci. 1993. Effects of induction of low plasma pro- 
gesterone concentrations with a progesterone-releasing intravaginal device on follicular turnover and fertility in cattle. J. Reprod. Fertil. 98:77-84

Sellars, C. B., J. C. Dalton, R. Manzo, J. Day, and A. Ahmadzadeh. 2006. Time and incidence of ovulation and conception rates after incorporating estradiol cypionate into a timed artificial insemination protocol. J. Dairy Sci. 89:620-626.

Senger, P. L. 1994. The estrus detection problem: New concepts, technologies, and possibilities. J. Dairy Sci. 77:2745-2753.

Shelton, K., M. F. Gayerie de Abreu, M. G. Hunter, T. J. Parkinson, and G. E. Lamming. 1990. Luteal inadequacy during the early luteal phase of sub fertile cows. J. Reprod. Fertil. 90:1-10.

Silper, B. F., A. M. L. Madureira, M. Kaur, T. A. Burnett, and R. L. A. Cerri. 2015. Short communication: comparison of estrus characteristics in Holstein heifers by 2 activity monitoring systems. J. Dairy Sci. 98:3158-3165.

Stevenson, J. S. 2011. Alternative programs to presynchronize estrous cycles in dairy cattle before a timed artificial insemination program. J. Dairy Sci. 94:205-217.

Stevenson, J. S. 2014. Impact of reproductive technologies on dairy food production in the dairy industry. Adv. Exp. Med. Biol. $752: 115-129$

Stevenson, J. S. 2016. Physiological predictors of ovulation and pregnancy risk in a fixed-time artificial insemination program. J. Dairy Sci. https://doi.org/10.3168/jds.2016-11247.
Stevenson, J. S., S. L. Hill, R. L. Nebel, and J. M. DeJarnette. 2014 Ovulation timing and conception risk after automated activity monitoring in lactating dairy cows. J. Dairy Sci. 97:4296-4308.

Stevenson, J. S., S. M. Tiffany, and M. C. Lucy. 2004. Use of estradiol cypionate as a substitute for $\mathrm{GnRH}$ in protocols for synchronizing ovulation in dairy cattle. J. Dairy Sci. 87:3298-3305.

Uehlinger, H., H. Binder, B. Hauser, P. Rüsch, and K. Zerobin. 1995 Comparison of vaginal devices CIDR and PRID in ovariectomized cows using hormone analysis. Schweiz. Arch. Tierheilkd. 137:81-86.

Vailes, L. D., and J. H. Britt. 1990. Influence of footing surface on mounting and other sexual behaviors of estrual Holstein cows. J. Anim. Sci. 68:2333-2339.

Valenza, A., J. O. Giordano, G. Lopes Jr., L. Vincenti, M. C. Amundson, and P. M. Fricke. 2012. Assessment of an accelerometer system for detection of estrus and treatment with gonadotropin-releasing hormone at the time of insemination in lactating dairy cows. J. Dairy Sci. 95:7115-7127.

Wiltbank, M., H. Lopez, R. Sartori, S. Sangsritavong, and A. Gumen 2006. Changes in reproductive physiology of lactating dairy cows due to elevated steroid metabolism. Theriogenology 65:17-29.

Zuluga, J. F., and G. L. Williams. 2008. High-pressure steam sterilization of previously used CIDR inserts enhances the magnitude of the acute increase in circulating progesterone after insertion in cows. Anim. Reprod. Sci. 107:30-35 